Cultures de bêtes... Outils qui pensent?

\title{
De l'intelligence humaine à celles des machines
}

Jacques Arsac

\section{OpenEdition}

Journals

Édition électronique

URL : https://journals.openedition.org/tc/564

DOI : $10.4000 /$ tc. 564

ISSN : 1952-420X

Éditeur

Éditions de l'EHESS

Édition imprimée

Date de publication : 1 novembre 1995

ISSN : 0248-6016

\section{Référence électronique}

Jacques Arsac, «De l'intelligence humaine à celles des machines », Techniques \& Culture [En ligne], 23-24 | 1995, mis en ligne le 09 décembre 2005, consulté le 29 septembre 2022. URL : http:// journals.openedition.org/tc/564; DOI : https://doi.org/10.4000/tc.564

Ce document a été généré automatiquement le 29 septembre 2022

Tous droits réservés 


\section{De l'intelligence humaine à celles des machines}

Jacques Arsac 